\title{
胃切除後食道癌に対する外科的治療の検討
}

\author{
福島県立医科大学第 1 外科 \\ *東北菌科大学外科 \\ 今野修渡辺正俊阿部幹 \\ 八子 直樹 渡辺善二郎遠藤 幸男 \\ 井上仁元木良一寺西寧*

\section{STUDIES ON SURGICAL TREATMENT OF ESOPHAGEAL CARCINOMA OCCURING AFTER GASTRECTOMY} \\ Osamu KonNo, Masatoshi WATANABE, Tsuyoshi ABE, \\ Naoki YAG0, Zenjiro WATANABE, Yukio ENDO, \\ Hitoshi INOUE, Ryoichi MOTOKI \\ and Yasushi TERANISHI* \\ First Department of Surgery, Fukushima Medical College \\ *Department of Surgery, Tohoku Dental University
}

胃切除後に発生した食道癌の外科治療上の問題点について自験例を中心に検討を加えた．対象例は 切除症例160例中 8 例 ( $5 \%$ ) であったが最近増加する傾向にある．既往疾患は良性が 6 例と多く，食 道癌発生までの期間は 10 年以上経過例が 5 例を占めた，術前の検査成績を通常の食道癌症例(対照例) と比較すると筫血，低蛋白の傾向にあったが有意ではなかった。

再建法は Im 症例は回結腸を, $\mathrm{Ei}$ 症例は空腸を用いた症例が多かった。手術時間, 術中出血量は対 照例に比べ大であり特に結腸再建例でその傾向が強かった。 また, 手術成績は直死 3 例，退院死 2 例 と不良であった。切除標本で 3 例に胃壁内食道癌の転移を認めており残胃の温存には慎重を期すべき である。

卖引用語：胃切除後食道癌, 残胃内食道癌転移, 異時性食道重複癌

I.はじめに

高齢者の増加および他藏器に対する手術成績の向上 とが相まって, 最近消化器手術既往をもつ食道癌症例 を経験することが多くなってきた，食道癌患者に対す る術前・術後管理, 手術手技の改善によって食道切除 術が比較的安全に施行できるようになってきたとはい 学, これら手術既往をもつ症例では, 再建臓器の選択 を含む再建法の問題, 再手術に伴う腹腔内瘾着による 手術操作上の問題, 術後消化吸収能などの問題がある. 本稿では教室におけるこれら消化器手術既往をるつ 症例のうち, 胃切除術後 (以下胃切後) 症例を中心に 検討した。

$<1989$ 年 5 月 8 日受理 $>$ 別刷請求先: 今野 修

下960-12 福島市光が丘 1 福島県立医科大学第 1 外 科

\section{II. 対 象}

昭和49年より63年 1 月末までに当教室に入院した消 化器手術既往をるつ食道癌症例は10例であったが, こ のらち Miles 手術後の 2 例を除き, 膵頭十二指腸切除 術を含む胃切除後症例 8 例を対象とした。これらはこ の間の原発性食道癌切除症例160例（切除率77.3\%)の $5 \%$ に相当した（表 1 ）.

\section{III. 結 果}

1) 癌占居部位

癌腫の主占居部位は $\mathrm{Ce} 1$ 例, Im 4 例, Ei 3 例で, 切除例に対する割合では Ce $4.2 \%, \operatorname{Im} 5.4 \%$, Ei $6.9 \%$ と Ei で高率であった（表 1 ）。

2）性別および年齢

性別では男性が 7 例（87.5\%）で女性 1 例，年齢は

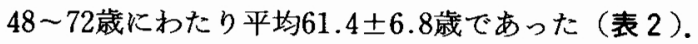


表 1 食道癌症例（昭和49－63. 1 末）

\begin{tabular}{|c|c|c|c|c|}
\hline 駔篮 & 入园 & 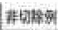 & 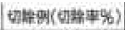 & 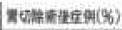 \\
\hline $\mathrm{Ce}$ & 29 & 5 & $24(82.8)$ & $1(4.2)$ \\
\hline Iu & 14 & 7 & $7(50,0)$ & $0(0)$ \\
\hline Im & 95 & 21 & $74 \quad(779)$ & $4(5: 4)$ \\
\hline Ei & 56 & 13 & $43(76.8)$ & $3^{*}(6.9)$ \\
\hline Ea & 13 & 1 & $12(923)$ & $0(0) 1$ \\
\hline if & 207 & 47 & $160(773)$ & $8(5)$ \\
\hline
\end{tabular}

表 2 胃切除後症例

\begin{tabular}{|c|c|c|c|c|c|c|c|}
\hline 路位 & No. & 性列 & 科) & 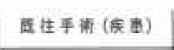 & 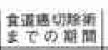 & 表 & 臬 \\
\hline $\mathrm{Ce}$ & 619 & t & 59 & 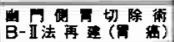 & 1年7 只月 & 渋下雨 & $2 \pi$ 月 \\
\hline \multirow{4}{*}{ im } & 7799 & t & 62 & 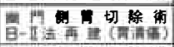 & 18年 & $2 \tan$ & 2 的 \\
\hline & $\$ 02$ & 8 & 63 & 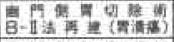 & 12年 & 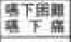 & 3 坵 \\
\hline & 1681 & 8 & 72 & 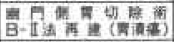 & $2543 t$ 月 & 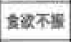 & 1 年月 \\
\hline & 1728 & है & 64 & 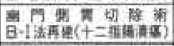 & 19年 & 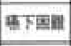 & 1 胡月 \\
\hline \multirow{3}{*}{ Ei } & 8241 & 8 & 48 & 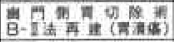 & $546 n$ 月 & 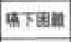 & 16月 \\
\hline & 9844 & 7 & 64 & 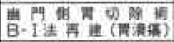 & 17年 & 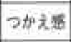 & 2 的月 \\
\hline & 10669 & t. & 59 & 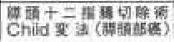 & 3年1市月 & 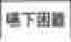 & 2 古月 \\
\hline
\end{tabular}

3）既往手術と疾患

既往手術および疾患は，1例は膵頭部癌に対する膵 頭十二指腸切除・Child 変法再建, 残りの 7 例は全例が 幽門側胃切除例であり，再建法は Billroth II 法（以下 B-II 法) が 5 例で, Billroth I 法（以下 B-I 法）は 2 例 のみであった，疾患別では胃・十二指腸潰瘍が 6 例,

胃癌が 1 例であった（表 2 ）.

4）食道切除術までの期間，主訴，病悩期間

既往手術より食道癌切除術までの期間は, 胃癌術後 の最短 1 年 7 かから胃潰瘍術後の最長 25 年 3 か月 で, 良性疾患に対する胃切後症例は 6 例中 5 例が 10 年 以上経過していた。

主訴は $\mathrm{Ce} の 1$ 例が嚥下痛, Im の 1 例が食欲不振で あったが，残りの 6 例はつかえ感および燕下困難で あった。また, 病悩期間は 1 か月〜 3 か月であった(表 2).

5) 術前検查所見

X 線所見に拈ける長径は, 最短 $2.5 \mathrm{~cm}$ から最長 $9 \mathrm{~cm}$ におよび平均 $6.2 \mathrm{~cm} \pm 2.4 \mathrm{~cm}$, 型は螺旋型が 4 例とい ちばん多く，境界は明瞭型が 5 例であった。

内視鏡所見では陷凹型が 5 例と大半を占め, その他 隆起型, 全周狭窄型, 表在隆起型がそれぞれ 1 例で, 腫瘍部分の内視鏡通過が不可能であった症例は 2 例で あった（表 3 ).

6）手術法および手術成績

i) 手術法

a) $\mathrm{Ce}$ 症例
表 3 術前 $\mathrm{X}$ 線・内視鏡所見

\begin{tabular}{|c|c|c|c|c|c|c|c|}
\hline \multirow{2}{*}{ No. } & \multicolumn{3}{|c|}{$\mathrm{X}$ 到形 } & \multicolumn{4}{|c|}{ 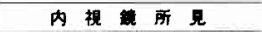 } \\
\hline & (m) & 䙵 & 塂界 & 㤠 & 굴 & 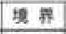 & मक्ज \\
\hline 619 & 35 & 䣯 & 䎳 & A $\mathrm{B}$ & 13 & An & 㝓 易 \\
\hline 7790 & 85 & 18 遍 & 明 到 & 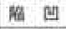 & 32 & 不然高 & 不可 \\
\hline 802 & $\theta$ & 14 政 & 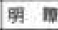 & 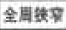 & 28 & Af $N$ & 寞 \\
\hline 1681 & 25 & 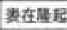 & 歌 韵 & 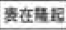 & 28 & 不蝴空 & 客聂 \\
\hline 1726 & 7.5 & it 然 & क㬰部 & 脆 U & 27 & F㖿国 & 不可 \\
\hline 8241 & 6 & 程裳 & 㩆 & 㭗山 & 33 & 明 要 & 客 要 \\
\hline 9844 & 8 & 61 & 不明策 & 脽凹 & 32 & 不明场 & 客 \\
\hline 10669 & 4.5 & 19 & 不明证 & 㴔 凹 & 43 & 不明位 & 客 \\
\hline
\end{tabular}

表 4 手術法

\begin{tabular}{|c|c|c|}
\hline 舆位 & No. & 手㖕 洼 \\
\hline $\mathrm{Ce}$ & 619 & 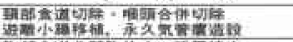 \\
\hline \multirow{4}{*}{ Im } & 7799 & 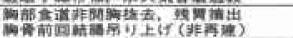 \\
\hline & 902 & 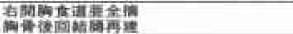 \\
\hline & 1681 & 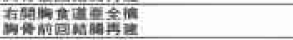 \\
\hline & 1726 & 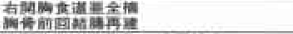 \\
\hline \multirow{3}{*}{$\mathrm{Ei}$} & 8241 & 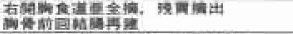 \\
\hline & 9844 & 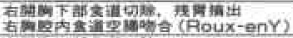 \\
\hline & 10669 & 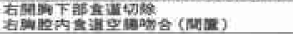 \\
\hline
\end{tabular}

胃癌に対しての B-II 法再建術後例であり，局所所見 より頸部食道喉頭合併切除を行い，遊離小腸移植で再 建された。

b) Im 症例

B-I 法 1 例, B-II 法 2 例の計 3 例で, 右開胸食道亜全 摘, 回結腸を用いた再建が行われ, 経路は胸骨後 1 例, 胸骨前 2 例であった。なたNo. 7799の 1 例はblunt dissection で胸部食道抜去残胃摘出後, 頸部食道瘦造 設と胸骨前につり上げた回結腸瘦造設で 1 期的再建を 回避された症例であった。

C) $\mathrm{Ei}$ 症例

B-II 法再建の 1 例は右開胸食道覀全摘残胃摘出後, 胸骨前回結腸間置を行い, B-I 法再建の 1 例は右開胸 下部食道切除，残胃摘出，右胸腔内食道空腸吻合 (Roux-en Y 法)で再建された. 膵頭十二指腸切除術後 の 1 例は右開胸下部食道切除後, 食道残胃間に空腸が 間置された（表 4 ）。

ii）手術成績

a およびn-factor による st III, IV の進行例が 5 例 と多かったが curability III を 3 例得ることができた。

しかし，術後縫合不全，心肺合併症などによる直死 例が 3 例 (37.5\%) と高率であった。ささらに $\mathrm{Ei} の 2$ 例 を, 再発（1年 2 か月）扣よび他病死（4 か月）のた め失った. 生存例は 3 例あり最長 2 年 5 か月で経過観 察中である(表 5 ).

7) 手術時間・術中出血量の比較 
表 5 手術成續

\begin{tabular}{|c|c|c|c|c|c|c|c|c|}
\hline 部位 & No: & a & $n$ & & $\mathrm{~A}$ & C & 行後合併症 & 7 \\
\hline $\mathrm{Ce}$ & 619 & 2. & 0 & III & II 1 & III & 표 & 245th生 \\
\hline \multirow{4}{*}{$\operatorname{lm}$} & 7799 & 0 & & tunt & & II & 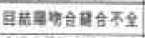 & 馬 \\
\hline & 902 & 0 & 3 & NI & III. & II & 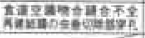 & 直 影 \\
\hline & 1681 & $\mathrm{mp}$ & 0 & I I & III. & III. & & 3th月生 \\
\hline & 1726 & 3 & 2 & 且 & I & 0 & a & $7 m^{2}$ 月坐 \\
\hline \multirow{3}{*}{$\mathrm{Ei}$} & 8241 & 1 & 2 & III & II & III & L & 亱 型 \\
\hline & 9844 & $\mathrm{mp}$ & 2. & II & II & II & 1 & 1年2 2 月月茾 \\
\hline & 10669 & $\mathrm{mp}$ & 1 & II & I & II & & $4 \pi^{2}$ 月死 \\
\hline
\end{tabular}

\section{表 6 手術時間・術中出血量の比較}

\begin{tabular}{|c|c|c|c|}
\hline & 手街 時用 & & 出血量 $(\mathrm{m} l)$ \\
\hline 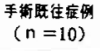 & 8 時間 57 分 $\div 2$ 時間 27 分 & & $1207 \pm 840$ \\
\hline $\begin{array}{c}\text { 対 照 例 } \\
(n=45)\end{array}$ & 7 時間17分 \pm 1 時間 41 分 & $7 P<0.01$ & $1043 \pm 603$ \\
\hline $\begin{array}{c}\text { 結腸再建例 } \\
(n=4)\end{array}$ & 10 時間 44 分 \pm 42 分 & & $1266 \pm 959$ \\
\hline
\end{tabular}

手術操作の繁雑さおよび侵襲の指標として手術既往 症例の手術時間と術中出血量を, 手術既往のない対照 例（45例）と比較した。

手術時間は既往症例 8 時間57分士 2 時間27分，対照 例 7 時間17分士 1 時間41分と既往症例で長い傾向があ る有意の差は認められなかった。

李た，出血量は症例により大きなバラッキがあり， 既往症例は $1,207 \pm 840 \mathrm{ml}$, 対照例 $1,043 \pm 603 \mathrm{ml}$ と著 差を認められなかった。

しかし, 結腸再建 4 例だけをみてみると, 手術時間 は10時間44分土42分と対照例に比べ有意に（p<0.05） 長かった（表 6 ).

8) 摘出標本所見

i) 食道の所見

摘出標本所見での肉眼型は潰瘍型が 6 例と大半を占 め, 境界の性状は明瞭 3 例, 中間 2 例, 不明瞭 1 例で あり, 残りの 2 例中 $\mathrm{Ce} の 1$ 例は隆起型・境界明瞭, Im の 1 例は表層型・境界明瞭であった。

また，瘵痕は術前放射線治療がなされた 4 例の5ち $40 \mathrm{~Gy}$ 照射の 2 例に認められた。

腫瘍の大きさは長径で $7 \mathrm{~cm}$ 以上の症例が 1 例, $3 \mathrm{~cm}$ 以上の症例が 5 例あり, $2 \mathrm{~cm}$ 以下の症例は 2 例のみで 平均3.6士1.7cm であった。

さらに, Pは Ce の 1 例が $0.5 \mathrm{~cm}$ と $1 \mathrm{~cm}$ 以下であり, DはEi 1 例でやはり $0.5 \mathrm{~cm}$ 以下であったが，他の 症例は全例 $2.5 \mathrm{~cm}$ 以上を保っていた。

食道内癌多発の症例は認められなかった（表 7 ）。
表 7 摘出標本所見

\begin{tabular}{|c|c|c|c|c|c|c|c|}
\hline No. & 肉期型 & 境 & gargas & $\neq 4$ & $P$ & & 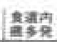 \\
\hline 619 & 陸 & 胉 & $(-)$ & $30 \times 2.0$ & 0.5 & 5.0 & $(-)$ \\
\hline 7799 & 证 & 不明16 & $(-)$ & $3.5 \times 2.0$ & 3.0 & 5.0 & $(-)$ \\
\hline 902 & 消 & 明 脾 & $(t)$ & $4.5 \times 3.0$ & 4.0 & 6.5 & $\Leftrightarrow$ \\
\hline 1681 & 妻 & 明 & $(-)$ & $2.0 \times 1.5$ & 4.0 & 6.5 & $(-)$ \\
\hline 1726 & 清 & 中 䦎 & $(\rightarrow)$ & $4.0 \times 1.5$ & 4.0 & 6.5 & $(-)$ \\
\hline 8241 & 消 & 明 & $(-)$ & $3.0 \times 2.5$ & 3.0 & 13.0 & $(-)$ \\
\hline 9844 & in & 中 & $(-)$ & $7.0 \times 3.5$ & 2.5 & 7.0 & $(-)$ \\
\hline 10689 & 洲 & 明 & (t) & $1.5 \times 1.0$ & 3.5 & 0.5 & $(-)$ \\
\hline
\end{tabular}

ii) 残胃の所見

残胃が摘出された症例は 3 例で, そのうちNo. 7799 の症例は, 術前より噴門部に腫瘤を認め, 摘出標本で 筋層内に一部変性壊死より囊包状となった食道癌の転 移が確認された。

また, No. 8241，No. 9844の 2 例は手術操作上の問 題で残胃が摘出されたが，No. 9844の症例では術前確 認されていなかった胃粘膜内扁平上皮癌の小胞巣が認 められた。

さらに，No. 902 症例では食道とともに一部切除 された胃の食道胃接合部の胃粘膜下層に，リンハ管侵 襲と小さい食道癌の転移が認められた(図 1，写真 1 ， $2,3)$.

\section{9) 合併療法}

放射線療法が施行された症例は 4 例あったが，全例 術前照射のみで, 照射量は40Gy が 2 例(Ef 3および Ef 2)，28Gy 1 例，20Gy 1 例であった.

また，化学療法が施行された症例は術前後で 5 例 あったが，レジメンは古い症例で Bleomycin 怙よび 5-Fluorouracil, 最近の症例では Cis-platinum が主体 であった。

10）術前臨床検查成績の比較

胃切後症例の術前栄養状態を，胃切除を受けていな い対照例（63例）と比較した。

末梢血液での赤血球（以下 RBC）は胃切後症例 $411.8 \pm 35.5 \times 10^{4} / \mathrm{mm}^{3}$ ，対照例 $414.5 \pm 57.1 \times 10^{4} /$ $\mathrm{mm}^{3}$, ヘマトクリット值（以下 Hct）渭切後症例 $38.6 \pm 2.2 \%$, 対照例 $39.3 \pm 5.2 \%$ と胃切後症例で低值 の傾向を示したが有意の差は認められなかった。

また，血清総蛋白量 (以下 TP)，およびアルブミン 量（以下 Alb）は胃切後症例でそれぞれ6.66士0.65g/ $\mathrm{dl}, 3.98 \pm 0.2 \mathrm{~g} / \mathrm{dl}$, 対照例でそれぞれ6.76士0.64g/dl, $4.12 \pm 0.49 \mathrm{~g} / \mathrm{dl}$ とやはり胃切後症例で低值であった が，有意の差は認められなかった（表 8).

術前体重も胃切後症例で $47.9 \pm 5.4 \mathrm{~kg}$ と対照例の 
図 1 胃壁内食道癌転移症例一標本シェーマー

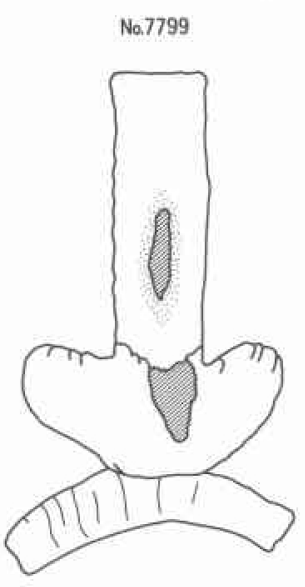

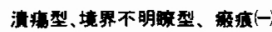
$3.5 \times 2.0 \mathrm{~cm}$ well.mp.ly $(+), v(t)$

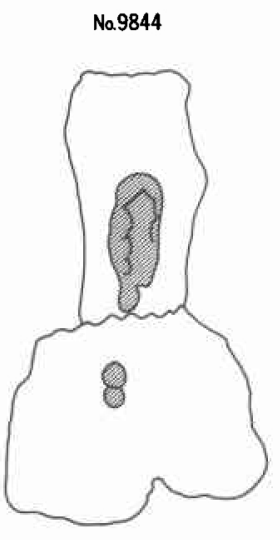

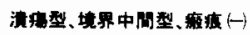

$7.0 \times 3.5 \mathrm{~cm}$

$\bmod , \operatorname{mp} . \operatorname{ly}(t), v(t)$
№.902

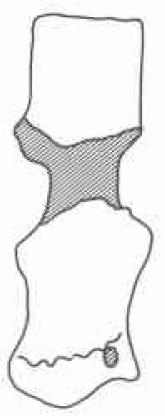

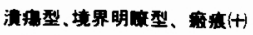

4. $5 \times 3.5 \mathrm{~cm}$

well, $a_{2}, \operatorname{ly}(-), v(\rightarrow$
写真 1

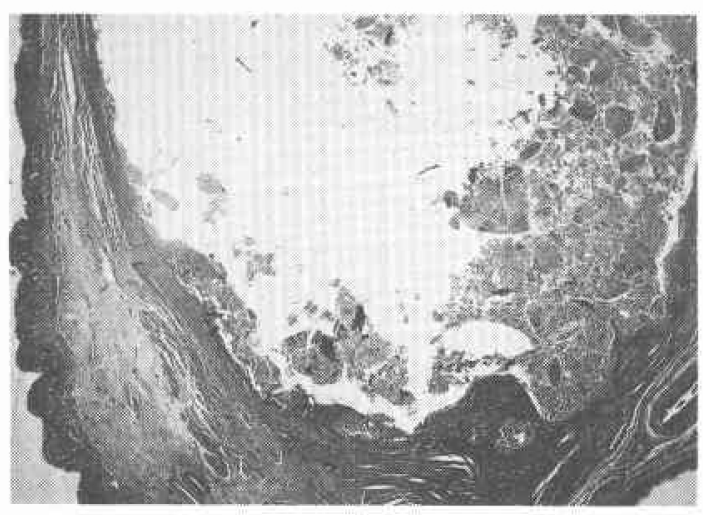

写真 2

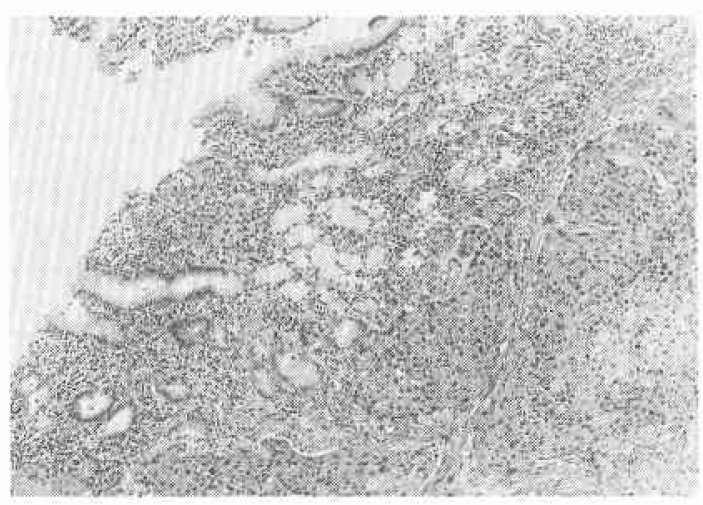

写真 3

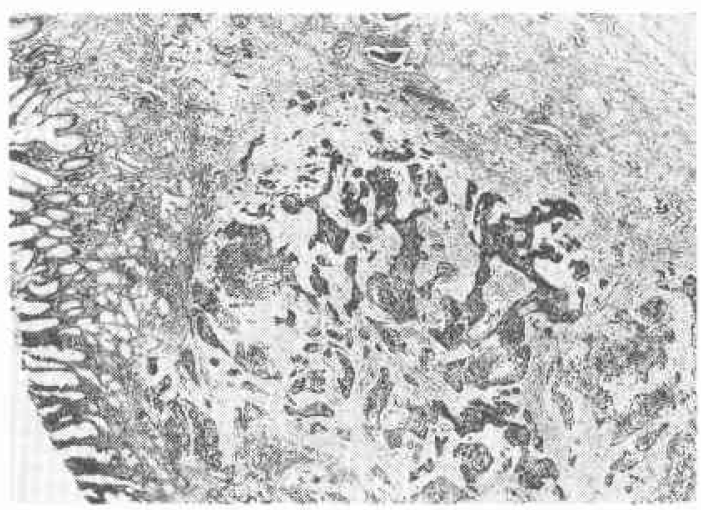

表 8 胃切除後症例の検查成績

\begin{tabular}{|c|c|c|c|c|c|}
\hline & 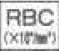 & $\begin{array}{l}\mathrm{Hct} \\
\text { (क) }\end{array}$ & $\mid \begin{array}{c}\text { T.P } \\
\text { (o/de) }\end{array}$ & 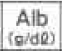 & $\begin{array}{c}\text { B.W } \\
\mathrm{KEE}\end{array}$ \\
\hline 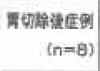 & $\frac{411.8}{ \pm} \frac{ \pm}{35.5}$ & $\frac{38.6}{ \pm .2}$ & $\frac{6.66}{\frac{ \pm}{0.65}}$ & $\begin{array}{l}3.98 \\
\pm \\
0.2\end{array}$ & $\frac{47.9}{ \pm}$ \\
\hline 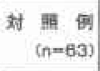 & $\begin{array}{c}414.5 \\
\pm \\
57.1\end{array}$ & $\stackrel{39.3}{ \pm}$ & $\frac{0.76}{ \pm} \frac{ \pm}{0.64}$ & $\frac{4.12}{ \pm} \frac{ \pm}{0.49}$ & $\begin{array}{c}51.5 \\
\pm \\
9.14\end{array}$ \\
\hline
\end{tabular}

$51.5 \pm 9.14 \mathrm{~kg}$ より低值であったが有意の差は認めら れなかった。

\section{IV. 考察}

食道癌を含む異時性重複癌症例の頻度は阿保らによ る1977年の第23回食道疾患研究会の集計1では1.5\% となっており, その5ち75\%が他葴器先行で, 重複癌 臓器は胃が37\%と最も多かったとしている。また, 1981 
年中山 ( $^{21}$ は当教室症例も含めた胃切後食道癌症例の 全国集計を行い詳細に検討し報告, 同時期の食道癌症 例数の母数が不明でその割合は定かではないが，症例 数は224例となっている.

1976年佐々木ら ${ }^{31}$ は自験例の検討で胃切後食道癌の 頻度は $2.6 \%, 1984$ 年前田ら4) の間 8 年の経過があり高踰者の増加, 他蔵器に対する 手術成績の向上などにより，経年的に増加しているこ とが考えられる．われわれの経験では膵頭十二指腸切 除術後症例を含めて 49 年以降の症例で $5 \%$ \%すった が， 5 例はここ 5 年間の症例であり，先に述べた理由 により，今後はますます増加するものと考克られる。

しかし，これらの症例においては，1）術式そのもの にかかわる再建臓器および再建経路の問題, 2) 開腹術 後のための癒着による実際の操作上の問題, 3) 術後栄 養消化機能などさまざまな問題があるがまだ十分に検 討されているとはいい難い，そこで，われわれはこれ ら胃切後食道癌症例について自験例を中心に検討し た。

性別では通常の食道癌症例同様, 男性が $87.5 \%$ と大 半を占め, 年齢は平均 61.4 歳で, 対照例の $61.8 \pm 9$ 歳 とほぼ同値であった。

また，癌占居部位は症例数では対照例同様 $\operatorname{Im} に$ 多 かったが, Ei 症例が 3 例 (37.5\%) を占め対照例での $\mathrm{Ei}$ 症例 $26.3 \%$ よ高率で, $\mathrm{Ei}$ 切除例中でも6.9\% と他 の部位より高率であった。これらは前田ら4と同様の 傾向であり，やはり胃切後の十二指腸液の逆流などが 関与5していることも考壳られる。

既往手術は良性疾患に対するものが大半で，中山 らの統計と同様であったが，今後は悪性疾患に対す る贯切後症例が増加してくることが予想される.

また, 胃切後食道癌発生までの期間は中山ら 計では 5 年以上が $71 \%$ であり， らち 10 年以上が $48.6 \%$ と約半数で, 特に良性疾患で長かったとし, 前田ら4 胃切除.となった既往疾患が悪性症例のほうが良性症例 より有意に（p<0.001）短期であったとしている。わ れわれの症例でも胃癌術後 1 年 7 か月の 1 例, 胃潰瘍 術後 5 年 6 力月, 脺頭十二指腸切除術後 3 年 1 か月の 3 例を除く 5 例 $(62.5 \%)$ が10年以上経過例で，やは り諸家の報告同様, 良性疾患儿対寸る胃切除後症例で 長かった.しかし B-I 法が 2 例と少ないため, 再建法に よる検討はできなかった。

主訴は対照例と比べて特記すべき違いは認められ ず，病悩期間も全例が 3 か月以内と対照例 $(n=102)$
の2.5土2.1か月と比較して著差を認めなかった，愁訴 が胃切除によるものとして放置されている可能性より 長くなるものとの予想に反し短期であったことは，む しろ術後であるといら状態が受診を早めたとも推察さ れる。

手術に抢ける再建経路について中山らの集計で は，胸骨後経路が $45.6 \%$ と最も多かったが，胸壁前経 路も32.8\%と通常例の $25 \%$ に比べ高値であった。 また， 再建葴器別では胃が使用できない場合が多いことより 当然のことであるが, 結腸が $72.2 \%$ と通常例の $6.3 \%$ 上 り有意に高く, 空腸の $24.4 \%$ も通常例の $5.8 \%$ に比べ高 值であった。われれの症例では，遊離小腸移植を行っ た Ce の 1 例と, 空腸を用いた $\mathrm{Ei} の 2$ 例を除く計 5 例 (62.5\%) で結腸が用いられた。

Ce 症例では早期で，下部食道に跳踓転移なく，䋛隔 リンハ節転移もないと判断された症例では遊離小腸移 植が有効な方法であると考兄られる。 Iu，Im の症例以

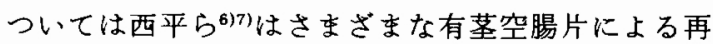
建を行い，良好な成績をおさめており，繁雑な感は否 めないが，有用な方法として評価される。

さらに Ei，Ea の症例では胸腔内吻合が比較的安全 に行いらるようになった現在では，下部食道切除のみ とし再建は結腸，小腸どちらでも習熟している缄器・ 方法で行えば良いと考えられるが，Eiについてやはり 開胸下に緹隔リンパ節郭清を行うのが必要と思われ る.

残胃を切除するかどうかに関しては, 癌腫の占居部 位が Eaであり，胃への浸潤がある場合には根治性の 点から切除することに異論はない(7)8)と考兄られるが, 他の場合には術後栄養の面から温存した方が良い? の報告もある。この際には同時性残胃癌がないことを 確認することが重要で, 特に術前胃内視鏡検査が施行 できなかった症例では芦沢らののいらょうに，必要に 応じて, 胃切開術, 術中迅速診断などを活用する必要 がある。

佐藤ら ${ }^{10}$ は $\mathrm{C}$ 領域の胃粘膜下腫湯は全例食道癌の 壁内転移であったとして，注意を促している，われわ れの症例では残胃摘出例が 3 例あり，そのうち 2 例に 扁平上皮癌の胃壁内転移を認め, さらに他の 1 例では 術後の全分割のプレパラートで食道胃接合部直下にや はり粘膜内微小転移巣を認めていることより，肉眼的 に判別できなくても，残胃を残すことにはかなり慎重 であるべきで，今後の検討が必要と考兄られた。

このように残胃に通常の食道癌症例では非常に稀有 
と考光られる扁平上皮癌の転移を認めることは, われ われの症例のみからは十分な検討はできなかったが， 何らかのリンバ流の変化が影響していることが示唆さ れた。

また, 胃切後の食道癌発生には胃切除に伴う栄養障 害や筫血などの関与を指摘する報告 ${ }^{11122}$ もあり，前田 ら4)は自験例10例でへモグロビン, RBC, TPなどを検 討, 通常の食道癌症例と比較し低值の傾向を認めたと している. 著者もこれらについて比較検討, 全検查に おいて低值であることが確認されたが, 有意の差は認 められなかった。

つぎに，既往手術が手術操作にどの程度影響を与え ているかを知るため胃切後症例を対照例と比較した が, 手術時間および術中出血量とも増大傾向を示した ものの有意の美は認められなかった。しかし, 結腸再 建例だけの検討では中山ら 2 の報告同様, 手術時間・術 中出血量ともに高値であり, 手術時間では有意差 $(\mathrm{p}<$ 0.01)を認め, 手術侵襲が大きいものと考兄られた。

\section{V.まとめ}

今後ますます増加してくると考えられる胃切除後食 道癌症例について教室で経験した症例を検討するとと もに, 文献的考察を行い以下の結論を得た。

1）昭和 49 年より 62 年末まで教室で切除した食道癌 症例160例中, 胃切除後症例は脺頭十二指腸切除例孔含 め 8 例（5\%）であった。

2）性別, 年龄は通常の食道癌症例とほぼ同值であっ たが，癌占居部位では $\mathrm{Ei} て ゙$ 切除例の $6.9 \%$ と高率で あった。

3）既往疾患は潰瘍が 6 例と多く，この中 5 例が食道 癌切除術まで10年以上経過していた.

4）手術成績は，合併症による直死が 3 例 (37.5\%) と高率であったが, 最長 2 年 5 か月を含め 3 例が生存 経過観察中である.

5）手術侵襲の指標として手術時間・術中出血量を通 常の食道癌症例と比較, 全例では著差を認めなかった が，結腸再建例の手術時間は有意に $(\mathrm{p}<0.01)$ 長かっ た。
6）残胃を摘出した 3 例中 2 例で嘪門部に食道癌の 転移を認め,さらに胃上部を合併切除した 1 例で食道 胃接合部直下の粘膜内に微小転移巣を認めていること より，残胃の温存には十分な注意が必要である。

7) 術前検查成績の RBC，Hct，TP，Albは胃切除 後症例で対照例に比べすべて低值であったが，有意の 差は認められなかった。

\section{文 献}

1）阿保七三郎, 三浦秀男, 工藤 保にか：日本に招け る食道と他臓器の重複癌について. 日消外会誌 $13: 377-381,1980$

2）中山隆市，青木明人，岡芹繁夫汪加：胃切除後・食 道癌の検討一本邦集計例を中心に一。 日消外会誌 $14: 1267-1278,1981$

3）佐々木公一, 藤巻雅夫, 川口正樹汪加：胃切除後に 発生した食道癌に対する外科的治療の検討. 日消 外会誌 $9: 1-7,1976$

4）前田迪郎, 古賀成昌, 金山博友ほか：胃切除後の食 道癌. 手術 $38: 1419-1424,1984$

5) Shearman DJC, Finlayson NDC, Arnott SJ et al: Carcinoma of the oesophagus after gastric surgery. Lancet $1: 581-582,1970$

6）西平哲郎, 丹 正義, 大森典夫ほか：有茎空腸片に 上る胃切除既往食道再建の改良と工夫. 日胸外会 誌 $32: 219-221,1984$

7）西平哲郎, 河内三郎, 平山 克ほか：有茎空腸片に 上る胃切後食道癌の再建術式. 手術 $37: 131$ $-138,1983$

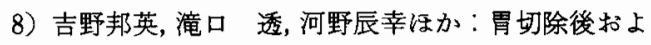
び胃に副病変をもった食道癌の外科治療. 手術 $38: 875-881,1984$

9）芦沢一喜, 森 昌造, 渡辺登志男ほか：食道と他缄 器との重複癌一とくに治療上の問題点について 一. 外科 $40: 627-631,1978$

10）佐藤裕俊, 佐藤 博, 磯野可一汪か：胃に異常を有 する食道癌の外科. 日胸外会誌 $26: 174-176$, 1978

11) Wright JT, Richardson PC: Squamous carcinoma of the thoracic oesophagus in malabsorption syndrome. Br Med J 1 : 540-542, 1967

12) Jacobs A: Anemia and post-cricoid carcinoma. Br J Cancer 15:736-744, 1961 